\title{
Sustainability and Equity Challenges to Pension Systems: The Case of Lebanon ${ }^{1}$
}

\author{
Mariusz Jarmuzek \\ mjarmuzek@imf.org \\ Najla Nakhle \\ nnakhle@imf.org
}

\begin{abstract}
Reform of Lebanon's pension system is indispensable. The country already faces fiscal sustainability risks, which will be compounded in the future by significantly higher pension- related spending and liabilities, mainly reflecting adverse demographics. In addition to sustainability issues, the pension system also suffers from equity shortcomings - Lebanon is the only MENA country that does not offer social security for retirees in the private sector. While several reform proposals have been formulated since the early 2000s, none has been implemented to date. Costs mount with every year of delay, so action is required soon to address these challenges.
\end{abstract}

JEL classification: E62, H55, J11

Key words: ageing, demographics, equity, pensions, pension reform, fiscal policy, sustainability

\section{INTRODUCTION}

Pension reform is an important policy challenge in many emerging markets (EM). Public pension expenditure averages around 6 percent of GDP in EM. While this is significantly lower than in some advanced economies, it nonetheless presents an important challenge looming on the horizon (IMF, 2014). Population aging and projected demographics make current pension systems unaffordable in the future, with risks to fiscal sustainability. At the same time, low pension coverage in many EM economies might leave large segments of the population without adequate income in old age and at risk of falling into poverty - thus raising important equity concerns.

\footnotetext{
The authors would like to express gratitude to Annalisa Fedelino for encouragement and detailed comments. Special thanks go to Mauricio Soto for providing conceptual advice and the framework for the analysis. The authors would also like to thank David Amaglobeli, Alain Bifani, Csaba Feher, Adnan Mazarei, Paulo Medas, Montserrat Pallares-Miralles, Andrew Tiffin, and the country team members for useful comments and discussions. The authors would also like to acknowledge the helpful comments provided by Mounir Rached and the teams of the Ministry of Finance and the Banque du Liban. Jonah Rosenthal provided excellent research assistance. Cecilia Pineda and Vanessa Panaligan provided excellent editorial and administrative support. Any remaining errors are our own. The views expressed in this paper are those of the authors and do not necessarily represent the views of the IMF, its Executive Board, or IMF management. An earlier version of the paper was published by Jarmuzek and Nakhle as an IMF Working Paper (2016).
} 
The challenge in Lebanon is even more pronounced. Although public pension expenditure for Lebanon currently amounts to 3 percent of GDP - about half the level in other EMs - consideration needs to be given to pension reform. Lebanon's population is ageing the fastest among Middle East and North Africa (MENA) countries and its social safety net for the elderly is considered highly inadequate by international standards (Pallares-Miralles and others, 2012; Rached, 2012). Beyond aging, the starting fiscal position and sustainability outlook for Lebanon are already weak, with public debt at above 130 percent of GDP in 2014 and projected to exceed 140 percent by 2020 (IMF, 2015).

Numerous proposals to reform the pension system in Lebanon have been considered, though they have been unsuccessful so far. Among them, three proposals put forward in the 2000s are worth noting. The 2004 proposal that the authorities attempted to implement in close collaboration with the World Bank aimed at integrating the public and private pension schemes into one modern fully-funded defined contribution scheme (World Bank, 2005). The 2011 proposal, prepared in close collaboration with the World Bank and the International Labor Organization, expanded on the 2004 proposal to offer medical insurance after retirement and a non-contributory pension scheme to all citizens funded by taxes (Rached, 2012). The most recent proposal that is currently under study within parliamentary committees envisages reforming the private pension scheme so that it provides lifetime health insurance and pension allowance, along with other important reform features.

However, as these initiatives were not implemented, the pension scheme has remained essentially unchanged since its introduction in the 1960s.

Lebanon is a country that faces significant challenges associated with demographic trends - it exhibits one of the worst trends in the MENA region. Based on the various policy simulations, the country faces fiscal sustainability risks associated with the generous public sector pension system and equity shortcomings due to low coverage. With respect to policy reform proposals whether partial or complete, Lebanon can provide very useful insights on how to tackle both sustainability and equity challenges. This paper provides an assessment of the fiscal risks associated with Lebanon's sustainability and equity challenges and reiterates the need for reforms. Building on the database compiled by Pallares-Miralles and others (2012), the paper presents underlying demographic trends for Lebanon and MENA countries that demonstrate the importance of the aging factor. These trends underpin projections of pension expenditures for public and private sector schemes under a no reform scenario. Having assessed the importance of the sustainability and equity challenges, the paper outlines key reform options, building on previous reform proposals formulated by the authorities in cooperation with international organizations. The paper however does not cover the issue of the broad macroeconomic impact of pension system reform.

The remainder of the paper is organized as follows. Section II describes the current pension system in Lebanon. Section III presents underlying demographic trends for Lebanon and MENA countries, followed by analyses of sustainability and equity of the current system. Section IV offers reform options, while Section V concludes.

\section{THE CURRENT PENSION SYSTEM}

Lebanon's pension system is based on separate schemes for public- and private-sector employees. The public sector schemes cover civil service and military personnel, while the private sector scheme only covers private sector and contractual government employees. 


\section{Public Sector Schemes}

Public-sector employees and military personnel have traditional defined-benefit schemes. Established in the early 1960s, they both grant an assured pension income, based on a pay-as-yougo system (Appendix Table A1). ${ }^{2}$

Both schemes are generous. The effective replacement rate is high and often close to 100 percent. $^{3}$ The system does not enforce a minimum retirement age, so that the accrual rate is high with respect to the retirement age and the contribution rate. ${ }^{4}$ In addition, the schemes are distorted by ad hoc and costly additional benefits - such as an extra lump-sum payment for retirees who complete 40 years of service, and the crediting of additional years of service for the military. Moreover, variations in pension payments are high as they are based only on the last salary level earned, which render them sensitive to career paths and wage histories.

Finally, the pension payments are indexed to changes in public sector salaries, making the system potentially vulnerable to large salary adjustments. ${ }^{5}$

Benefits are particularly generous to surviving heirs of retirees. Surviving wives and heirs of retirees retain the full pension of the deceased employee. Unmarried, divorced and widowed daughters of retirees keep the pension benefits for life. Taking these extended beneficiaries into consideration, calculations that account for life expectancy for men and women, standard age difference between husbands and wives, and daughters' claims on pensions show that pensions are drawn for an average of 30 years after a particular public servant's retirement - compared to an average lifetime career of 40 years (Daher, 2012).

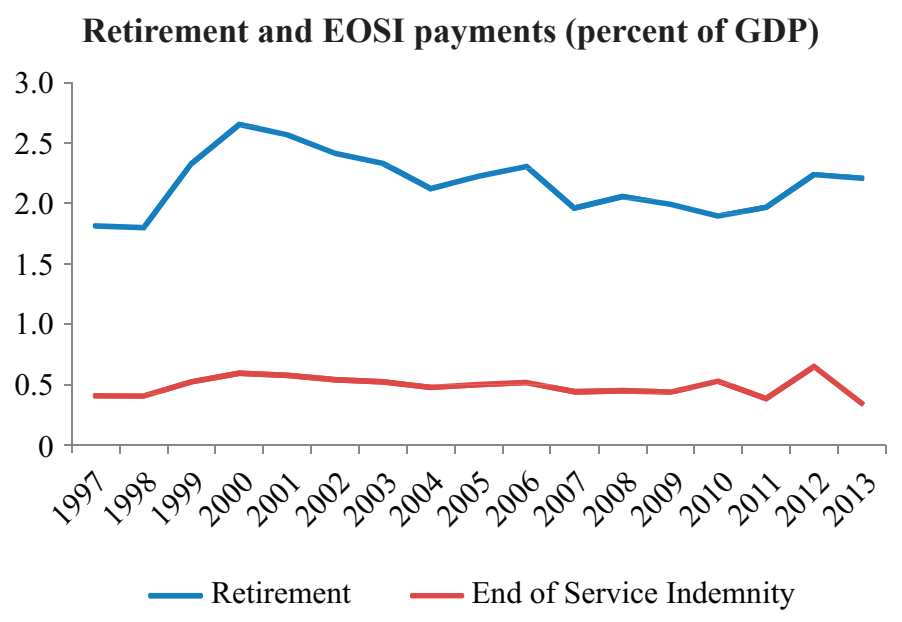

Despite their multiplicity, end-of-service-indemnity (EOSI) lump-sum disbursements in the public sector have historically been much lower than pension payments (text chart). These payments are mandatory for forced terminations and for teachers who have served less than 25 years (20 years for administrative staff and female teachers who resign for marriage purposes); for teachers (administrative staff) who serve 25 (20 years) or above, lump-sum indemnity would be optional. For the military, terminated employees and officers who serve less than 20 years

\footnotetext{
2 The pension scheme for public servants follows the 1959 Public Servants System Legislative Decrees; that of the military follows a 1961 legislative decree.

3 The replacement rate is 85 percent, pensions are tax exempt, and public sector retirees do not contribute to the pension scheme

4 The accrual rate, normally a function of retirement age, life expectancy at retirement, and the contribution rate, is the percentage of the income that the worker receives for each year of contribution.

5 Salary scale adjustments are irregular but very large when they occur. A substantial increase of public sector wages has been debated since 2012. If approved, it is expected to add more than 1 percent of GDP to the annual wage bill. It includes three components: (i) an increase in the minimum wage to $\$ 448$ from $\$ 332$ - a minimum wage increase for the private sector was last implemented in 2008 - it raised the minimum wage from $\$ 199$ to $\$ 332$; (ii) the application of a cost of living adjustment last granted for the public sector in 1999 and (iii) the adoption of a new salary scale - last updated in 1998.
} 
(10 years for non-officers) are only eligible for a lump-sum indemnity; those who serve 20 years (10 years) or more have a choice between pension and lump-sum payments.

Public sector employees who serve for more than 40 years receive a lump-sum top up worth 85 percent of the last monthly basic salary times three months for each year of service that exceeds 40 years. Most men choose pension payments while many women choose lump-sum payments because if both are public sector employees the latter would inherit their husband's pension for life.

\section{Private Sector Scheme}

Private sector employees predominantly rely on a defined-contribution scheme. The main scheme is administered by the National Social Security Fund (NSSF), an independent institution established in 1963 under the Ministry of Labor. An EOSI offers a lump-sum cash benefit upon retirement - equivalent to the accumulated contributions associated with past employers, and one month of earnings for each year of service with final employer (up to 20 years, with half a month for each year in excess of 20 years, for those aged more than 60, Appendix Table A2). Aside from the scheme administered by the NSSF, other schemes exist for universities, syndicates and private sector teachers (Box 1).

Benefits are very limited. As all benefits are terminated with a single lump-sum payment upon retirement, employees lose all benefits post-retirement - when they need them the most. There are no further pension or health coverage benefits after retirement. Furthermore, NSSF coverage is provided only to private-sector and contractual government employees, leaving out the elderly. ${ }^{6}$

\begin{tabular}{l} 
Box 1. Other Private Sector Schemes \\
Universities: The public university and private universities require contributions ranging \\
between 5 and 11 percent of the employee's earnings to finance their pension schemes. The \\
schemes offer mostly defined benefits that depend on the last earned salary and the number \\
of years of service; the investment of the funds is delegated to private insurance companies. \\
Many universities offer life insurance and disability benefits and pay funeral expenses for \\
their members, as well as education allowances. They also offer health insurance. \\
Private syndicates: Lawyers, engineers, physicians, and pharmacists offer their own social \\
security schemes that provide regular pension payments upon retirement as well as health \\
coverage. These defined contribution schemes are optional and extend to family members. \\
Private schools: Private sector teachers have their own optional pension scheme offering an \\
indemnity that can be converted into a regular pension as well as health insurance coverage. \\
The indemnity is a lump sum worth one month salary for each of the first 10 years, two \\
months for each of the following 20 years, and three month salary for each year beyond the \\
first 30 years. The pension scheme provides regular pension payment worth 85 percent of the \\
last salary for members who serve at least 30 years. The plan is financed by a contribution of \\
6 percent of the member's salary topped by a similar amount by the school. \\
\hline
\end{tabular}

The NSSF was supposed to include an optional contributory and subsidized scheme for the elderly - not activated to date - requiring a contribution of 6 percent of the minimum monthly wage by each subscriber. 


\section{SUSTAINABILITY AND EQUITY}

This section presents key challenges that Lebanon is facing to ensure the pension system's sustainability while providing social protection. The analysis is underpinned by pension expenditure projections based on demographic trends under a no reform scenario.

\section{Methodology}

To project pension expenditure, a basic identity decomposing the drivers of pension expenditure (PE) into three main categories is used: the replacement rate (ratio of average pensions divided by average wages); aging (measured by the old age dependency ratio); and the coverage (the number of pensioners as a proportion of the population 65 and older). ${ }^{7}$

$$
\frac{P E}{G D P}=\underbrace{\frac{\text { Expenditure }}{\text { Pensioners }} / \frac{G D P}{W A P}}_{\text {Replacement rate }} * \underbrace{\frac{\text { Pensioners }}{\text { WAP }}}_{\begin{array}{c}
\text { Old-age } \\
\text { dependency } \\
\text { ratio }
\end{array}} * \underbrace{\frac{\text { Pensioners }}{\text { Old age population }}}_{\text {Coverage }}
$$

WAP is working age population. Using this identity, it is possible to calculate the change in pension spending as a share of GDP between two years ( $\mathrm{t} 1$ and $\mathrm{t} 2)$. For any year $\mathrm{t}$, let $\mathrm{O}(\mathrm{t})$ be the old-age dependency ratio, $\mathrm{C}(\mathrm{t})$ be the coverage ratio, $\mathrm{R}(\mathrm{t})$ be the replacement rate.

Assuming a constant total compensation share in GDP over time yields:

$$
\frac{P E}{G D P}\left(\mathrm{t}_{2}\right)=\frac{P E}{G D P}\left(\mathrm{t}_{1}\right) * \frac{O\left(\mathrm{t}_{2}\right) * C\left(\mathrm{t}_{2}\right) * R\left(\mathrm{t}_{2}\right)}{O\left(\mathrm{t}_{1}\right) * C\left(\mathrm{t}_{1}\right) * R\left(\mathrm{t}_{1}\right)} .
$$

Assuming further that replacement rate and coverage remain constant over time, the main focus of the analysis becomes assessing the impact of aging.

\section{Underlying Demographic Trends}

Significant demographic challenges are looming on the horizon for Lebanon.

- Life expectancy. Lebanon has the highest life expectancy in the MENA region, around 80 years as of 2012, which is projected to increase by more than 6 years by 2050 .

- Fertility. At the same time, Lebanon has the lowest fertility rate in the MENA region. While the fertility rate is around 1.5 children per female as of 2012, the average for the MENA region is 2.7. Going forward, Lebanese fertility is expected to develop broadly in line with the MENA region

- Dependency ratio. The dependency ratio is defined as the population 65 and older, relative to the working age population. With greater life expectancy and lower fertility, the ratio is projected to exceed 30 percent for Lebanon by 2050 . This would be the highest in the MENA region, for which the average is around 20 percent. 
Demographic Indicators. MENA Region, 2012

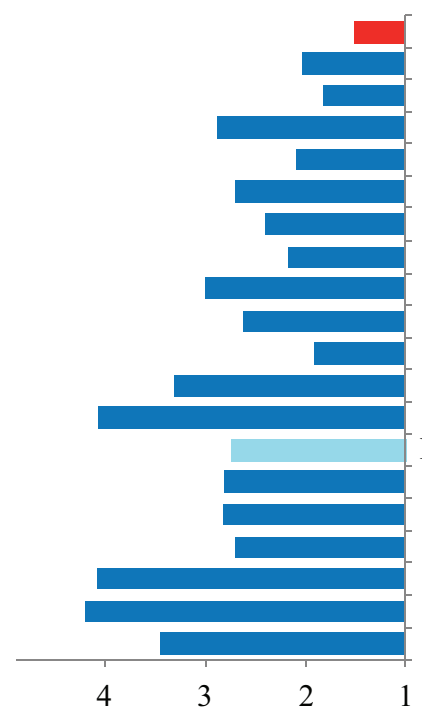

Fertility Rate (births per female)

Source: World Development Indicators

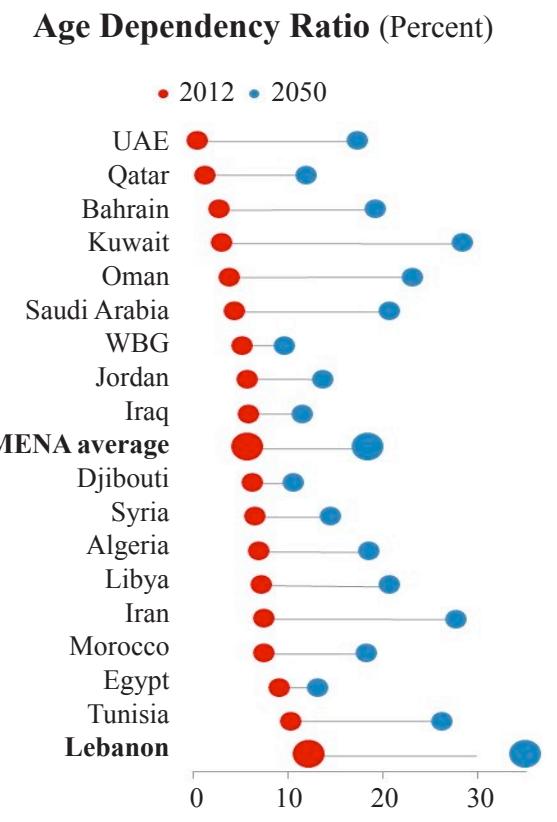

Source: World Development Indicators, UN

\section{Sustainability}

Given the already challenging fiscal sustainability outlook and identified unfavorable demographics, it is important to quantify the extent to which pension expenditure might add to this issue. Since there are separate schemes for public and private sector employees, the analysis is split to account for this feature.

\section{Public sector schemes}

The projected path of public pension expenditure is explosive. With the above demographic trends, expenditure would increase from around 3 percent of GDP in 2014 to 5.2 percent in 2030, and accelerate significantly after that, reaching around 9 percent of GDP in 2050. This is high by international standards, where the average projected pension expenditure for emerging market countries is estimated at 8 percent of GDP by 2050. The cumulative cost of this projected increase is substantial, as illustrated by the present discounted value (PDV) of increased spending over 20142050, estimated at almost 80 percent of 2015 GDP. This is again high by emerging market standards, for which the projected increase in PDV is estimated at around 25 percent of 2015 GDP (Table 1).

Table 1.

Pension Expenditures on Public Sector Schemes

\begin{tabular}{|c|c|c|c|c|c|c|c|c|c|c|c|c|}
\hline & \multirow{2}{*}{\multicolumn{6}{|c|}{$\begin{array}{c}\text { Pension Expenditure } \\
(\% \text { of GDP })\end{array}$}} & \multicolumn{3}{|c|}{ 2014-2030 } & \multicolumn{3}{|c|}{ 2014-2050 } \\
\hline & & & & & & & \multicolumn{2}{|c|}{ Expenditure Increase } & \multirow{2}{*}{$\begin{array}{l}\text { Accrued } \\
\text { Pension } \\
\text { Liability } \\
\text { (\% of } \\
\text { GDP) }\end{array}$} & \multicolumn{2}{|c|}{ Expenditure Increase } & \multirow{2}{*}{$\begin{array}{c}\text { Accrued } \\
\text { Pension } \\
\text { Liability } \\
\text { (\% of } \\
\text { GDP) }\end{array}$} \\
\hline & 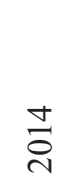 & $\stackrel{n}{\circ}$ & ণิ & ฮู & હ) & in & $\begin{array}{l}\text { Percentage } \\
\text { Points }\end{array}$ & $\begin{array}{c}\text { Present } \\
\text { Discounted } \\
\text { Value } \\
(\% \text { of GDP) }\end{array}$ & & $\begin{array}{l}\text { Percentage } \\
\text { Points }\end{array}$ & $\begin{array}{c}\text { Present } \\
\text { Discounted } \\
\text { Value } \\
\text { (\% of GDP) }\end{array}$ & \\
\hline Lebanon & 3.0 & 3.0 & 3.3 & 4.2 & 5.2 & 9.1 & 2.2 & 12.6 & 53.4 & 6.1 & 76.9 & 109.7 \\
\hline $\begin{array}{l}\text { Emerging } \\
\text { Average }\end{array}$ & 5.8 & 5.8 & 5.9 & 6.2 & 6.5 & 8.0 & 0.7 & 3.7 & 90.9 & 2.1 & 24.3 & 147.4 \\
\hline
\end{tabular}


Assuming no reform, projected pension spending will undermine fiscal sustainability. The projected increase of 6 percentage points of GDP in nominal terms and of 77 percentage points in PDV terms by 2050 pose significant challenges to fiscal policy. In particular, the projected increase in PDV terms essentially implies taking on (and financing) 77 percent of additional debt, on top of an already-very high debt burden. The accrued pension liability - estimated at close to 110 percent of GDP in 2050 - also suggests significant fiscal risks.

\section{Private sector scheme}

While the projected pension expenditure for the private scheme increases in line with that for the public sector, the magnitude is much smaller. Under the same demographic dynamics, spending increases from 0.5 percent of GDP in 2014 to almost 1 percent in 2030, accelerating significantly to 1.5 percent of GDP in 2050 (Table 2). Estimates of the projected increase in PDV terms confirm the relatively small impact on expenditure over the long term.

Table 2.

Pension Expenditures on Private Sector Scheme

\begin{tabular}{|c|c|c|c|c|c|c|c|c|c|c|c|c|}
\hline & \multirow{2}{*}{\multicolumn{6}{|c|}{$\begin{array}{c}\text { Pension Expenditure } \\
(\% \text { of GDP })\end{array}$}} & \multicolumn{3}{|c|}{ 2014-2030 } & \multicolumn{3}{|c|}{ 2014-2050 } \\
\hline & & & & & & & \multicolumn{2}{|c|}{ Expenditure Increase } & \multirow{2}{*}{$\begin{array}{c}\text { Accrued } \\
\text { Pension } \\
\text { Liability } \\
\text { (\% of } \\
\text { GDP) }\end{array}$} & \multicolumn{2}{|c|}{ Expenditure Increase } & \multirow{2}{*}{$\begin{array}{c}\text { Accrued } \\
\text { Pension } \\
\text { Liability } \\
\text { (\% of } \\
\text { GDP) }\end{array}$} \\
\hline & ঠ & $\stackrel{n}{\circ}$ & ণิ & ๙ู & હి & ஜ̊ & $\begin{array}{l}\text { Percentage } \\
\text { Points }\end{array}$ & $\begin{array}{c}\text { Present } \\
\text { Discounted } \\
\text { Value } \\
\text { (\% of GDP) }\end{array}$ & & $\begin{array}{l}\text { Percentage } \\
\text { Points }\end{array}$ & $\begin{array}{c}\text { Present } \\
\text { Discounted } \\
\text { Value } \\
(\% \text { of GDP })\end{array}$ & \\
\hline Lebanon & 0.5 & 0.5 & 0.6 & 0.7 & 0.9 & 1.5 & 0.4 & 2.1 & 8.9 & 1.0 & 12.8 & 18.3 \\
\hline
\end{tabular}

Source: UN, Staff calculations

In contrast to the public schemes, the private-sector increase does not threaten fiscal sustainability. The projected increase of 1 percentage points of GDP in nominal terms and of more than 10 percentage points of GDP in PDV terms by 2050 could be offset by fiscal adjustment and/or running down NSSF reserves. But, if revenues were held steady as a share of GDP, and spending increased in line with demographic trends, the overall NSSF balance would be reduced to almost zero by 2050 (Table 3). In addition, the lack of a transparent link between subscriber contributions and benefits could give rise to additional liabilities. Though these are not covered by the NSSF and would be the obligation of the final employer, they are nonetheless a contingent liability as the latter might not be able to pay.

Table 3.

Simulation of Sustainability of Private Sector Scheme

\begin{tabular}{lccccc}
\hline \hline & \multicolumn{5}{c}{ End of service idemnity (percent of GDP) } \\
\cline { 2 - 6 } & 2015 & 2020 & 2025 & 2030 & 2050 \\
\hline Revenue & 1.9 & 1.9 & 1.9 & 1.9 & 1.9 \\
Expenditure & 0.5 & 0.5 & 0.7 & 0.9 & 1.5 \\
Overall balance & 1.4 & 1.4 & 1.2 & 1.0 & 0.4 \\
\hline \hline
\end{tabular}

Source: UN, Staff calculations 


\section{Equity}

Coverage of the pension system is limited. While broadly in line with the MENA average - when measured as the share of members relative to the labor force or working age population coverage for both public and private schemes is somewhat low by international standards. At the same time, these indicators do not completely capture the nature of Lebanon's private-sector pension system, which provides only a lump-sum and not a pension per se. As a result, focusing on beneficiary coverage indicators results in low coverage by MENA standards. Specifically, both old-age beneficiaries and total beneficiaries are well below the MENA average, as a fraction of total population.

Pension System Coverage. MENA Region, 2012

Active Coverage Ratios (percent)
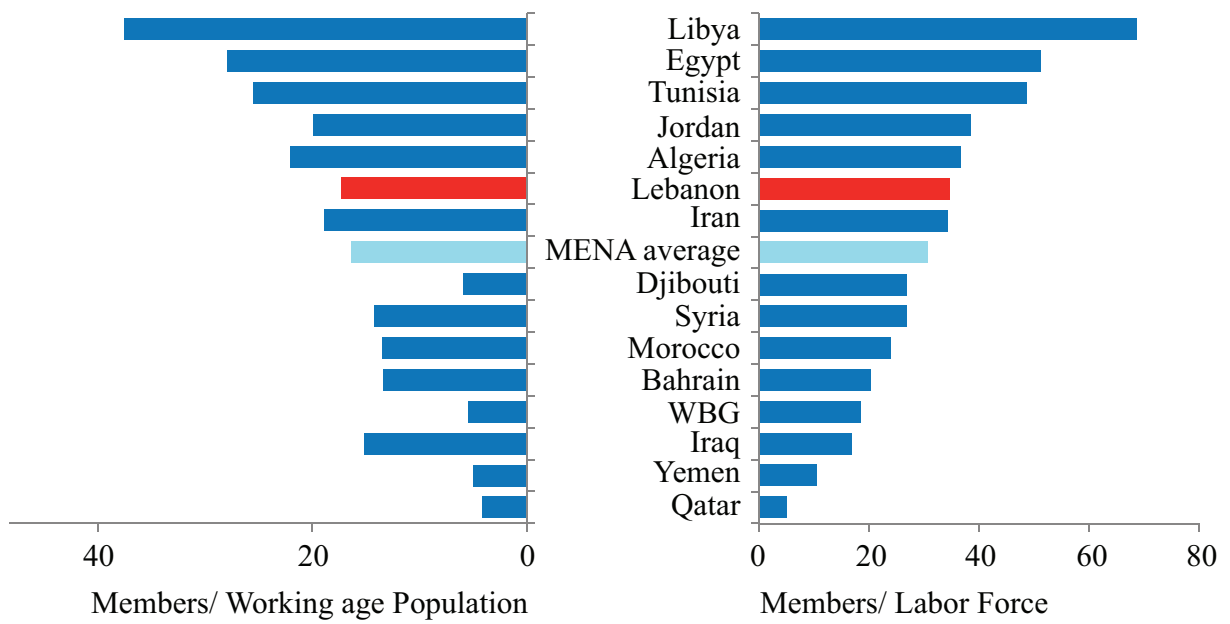

Beneficiaries Coverage Ratios (percent)
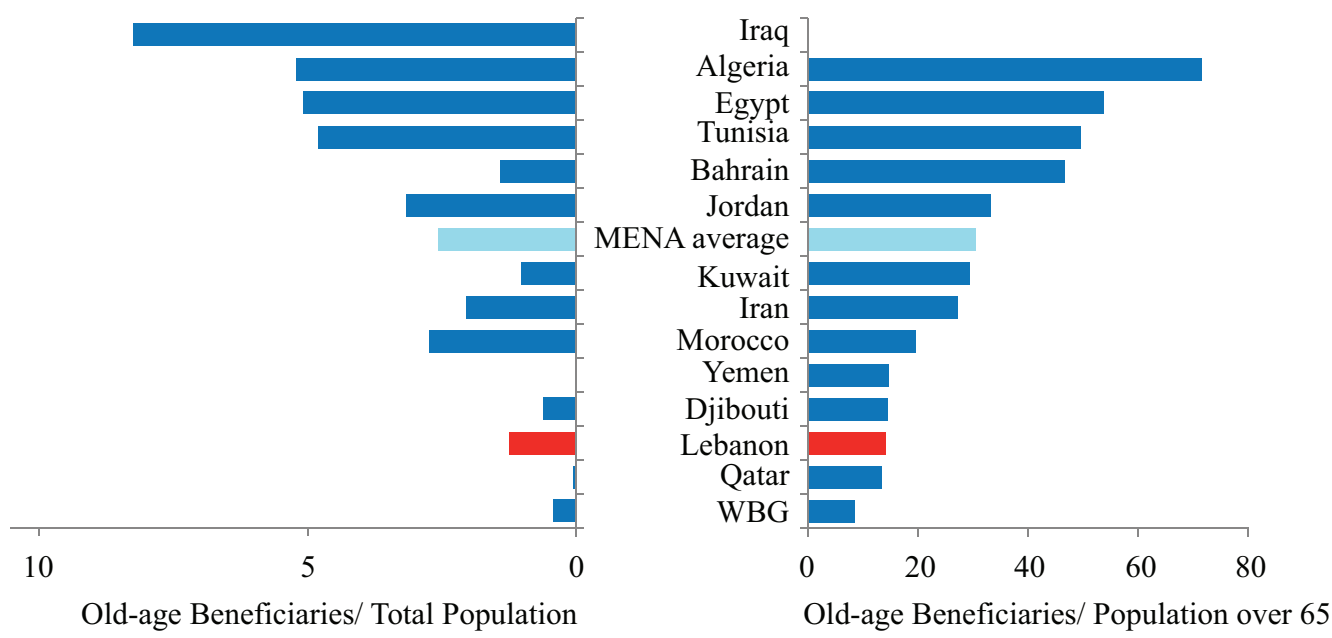

Source: World Bank.

Coverage modalities differ across the public and private schemes, increasing their inequity.

- The public sector schemes offer to the average full-career worker a pension equivalent to around 85 percent of pre-retirement income, combined with no income tax and continued healthcare insurance cover. In contrast, the private sector scheme offers a much lower equivalent of preretirement income (paid as a lump-sum); and retirees lose access to health coverage. 
- Financial and longevity risks differ. Under the private scheme, employers face financial risk because the final employer is supposed to pay the difference between the dues to the employee and the actual amount of money in his/her account. In addition, employers face longevity risk as the increased life expectancy can result in payouts higher than originally envisaged. This is in sharp contrast to the public pension schemes where both financial and longevity risk are assumed by the government.

Beyond coverage, there is however a broader issue of a social safety net for the elderly in Lebanon. In general, spending on social protection in Lebanon is low by MENA standards. On top of that, Lebanon is the only country in MENA that does not offer social security for retirees in the private sector, so the most vulnerable elderly are left without any formal lifetime pension coverage. Furthermore, Lebanon has the highest percentage of older adults who continue to work beyond the age 60 - suggesting that most of these workers would be self-employed or employed in the informal sector with no access to any type of old age pension (Yount and Sibai, 2008).

Public Spending for Social Protection, 2013

(percent of GDP)

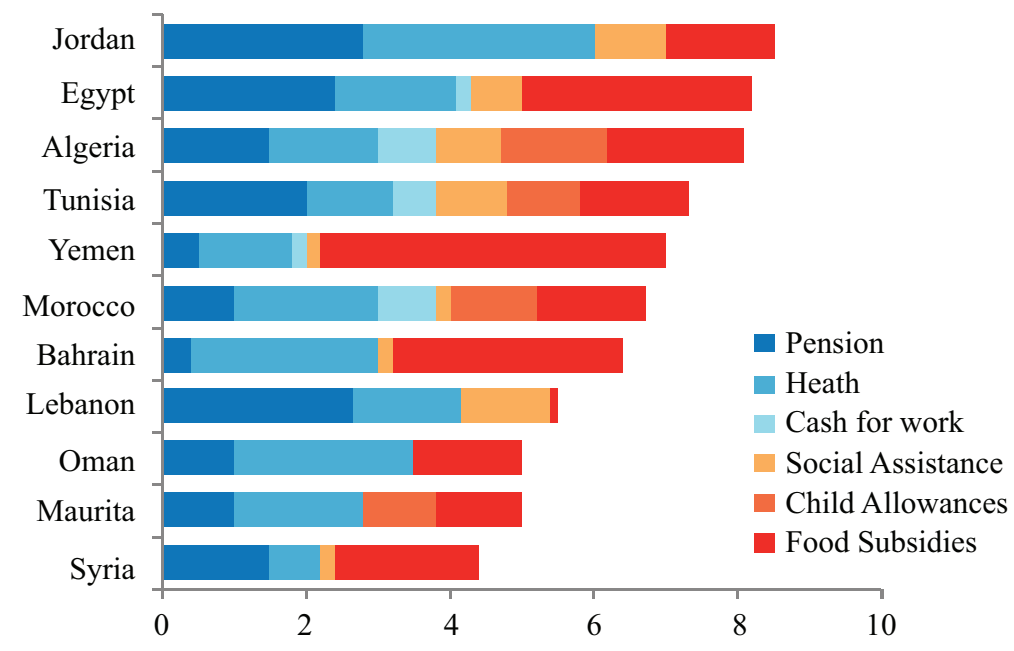

Source: IMF staff calculations based on Loewe, 2013

\section{REFORM OPTIONS}

Various options could help address sustainability and equity challenges. In this section, we explore options that include partial reforms and a transition to a unified pension system.

\section{Partial Reforms}

Given sustainability concerns, both public and private sector schemes should be reformed. Building on World Bank (2005), selected parametric options include: (i) increasing retirement age; (ii) containing benefits; and (iii) increasing social contributions.

\section{Public sector schemes}

- Retirement age. A higher retirement age would be warranted by Lebanon's relatively high life expectancy, along with the fact that the effective retirement age is significantly lower than the statutory retirement age. An increase by 4 years by 2030 could lower pension expenditure by 1.1 percent in 2030 and by 1.8 percent in 2050 . 
- Benefits. Another option would be to delink pensions from wages in the public sector and reduce some of the current benefits.

- Indexation of benefits. The current indexation formula exposes the pension schemes to potentially high and unexpected wage adjustments. Delinking pensions from wages and indexing them instead to inflation can potentially save 0.7 percent by 2030 and 1.6 percent by 2050 .

- Benefit reduction. The replacement ratio - effectively close to 100 percent - could also be reduced. Eliminating allowances and lump-sums for individuals who opt for pensions could reduce benefits by around 5 percent, which could in turn potentially reduce pension expenditures by 0.4 percent of GDP by 2050 .

- Social contributions. The current contribution rate is only 6 percent. Increasing social contributions by 4 percent could bring down pension expenditures by 1 percent of GDP by 2050 .

Table 4.

Reform Options for Public Sector Schemes

\begin{tabular}{|c|c|c|c|c|}
\hline & \multicolumn{4}{|c|}{ Expenditure Increase } \\
\hline & \multicolumn{2}{|c|}{ 2014-2030 } & \multicolumn{2}{|c|}{ 2014-2050 } \\
\hline & $\begin{array}{l}\text { Percentage } \\
\text { Points }\end{array}$ & $\begin{array}{l}\text { Present Discounted } \\
\text { Value (\% of GDP) }\end{array}$ & $\begin{array}{l}\text { Percentage } \\
\text { Points }\end{array}$ & $\begin{array}{l}\text { Present Discounted } \\
\text { Value ( } \% \text { of GDP) }\end{array}$ \\
\hline Baseline Projection & 2.2 & 12.6 & 6.1 & 76.9 \\
\hline Retirement Age Increase & -1.1 & -8.2 & -1.8 & -30.1 \\
\hline Indexation of Benefits & -0.7 & -4.2 & -1.6 & -21.6 \\
\hline Benefit Reduction & -0.1 & -0.8 & -0.4 & -4.6 \\
\hline Increase Social & -1.0 & -15.7 & -1.0 & -31.1 \\
\hline $\begin{array}{l}\text { Baseline + Reforms } \\
\text { Contributions (offset) }\end{array}$ & -0.7 & -16.3 & 1.4 & -10.5 \\
\hline
\end{tabular}

Source: UN, Staff calculations

\section{Private sector scheme}

Different reform options may be required for the private sector scheme. Its lump-sum nature, which leaves retirees unprotected in many respects, could be to a certain extent addressed by annuitization. As benefits are limited, the following parametric reform options could be considered:

- Retirement age. As for the public sector schemes, the retirement age could be increased. An increase by 5 years by 2030 could result in a decrease in pension expenditure by 0.2 percent of GDP in 2030 and by 0.4 percent of GDP in 2050.

- Social contributions. Building on the assumption of annuitization, private sector employees could contribute to a lifetime pension system in line with the employees of the public sector. Private sector employees are currently subject to a zero contribution rate because they are not entitled to any post-retirement benefits, but to be consistent with the public sector schemes, a contribution of 10 percent could be considered. As a result, pension expenditures could be reduced by 2.5 percent of GDP 2050, which would generate surpluses. 
Table 5.

Reform Options for Private Sector Scheme

\begin{tabular}{|c|c|c|c|c|}
\hline & \multicolumn{4}{|c|}{ Expenditure Increase } \\
\hline & \multicolumn{2}{|c|}{ 2014-2030 } & \multicolumn{2}{|c|}{$2014-2050$} \\
\hline & $\begin{array}{l}\text { Percentage } \\
\text { Points }\end{array}$ & $\begin{array}{l}\text { Present Discounted } \\
\text { Value ( } \% \text { of GDP) }\end{array}$ & $\begin{array}{l}\text { Percentage } \\
\text { Points }\end{array}$ & $\begin{array}{l}\text { Present Discounted } \\
\text { Value (\% of GDP) }\end{array}$ \\
\hline Baseline Projection & 0.4 & 2.1 & 1.0 & 12.8 \\
\hline Retirement Age Increase & -0.2 & -1.7 & -0.4 & -6.2 \\
\hline $\begin{array}{l}\text { Increase Social } \\
\text { Contributions (offset) }\end{array}$ & -2.5 & -39.3 & -2.5 & -77.8 \\
\hline Baseline + Reforms & -2.4 & -38.8 & -1.8 & -71.1 \\
\hline
\end{tabular}

Source: UN, Staff calculations

The most recent proposal that is more comprehensive in nature, but is still under study within parliamentary committees, envisages reforming the private pension scheme so that it provides lifetime health insurance and pension allowance, along with other important reform features (Box 2).

\section{Box 2. Current Proposal for Reform in Private Sector Scheme}

The most recent draft law on pension and social security (LEA, 2014) that aims at reforming the private sector scheme is currently under study within parliamentary committees. This law proposes amending some of the articles of the NSSF law to replace the existing EOSI system. The proposal entails the establishment of a pension and social security system the Retirement, Disability and Death Fund - that will fully substitute the EOSI and that will provide three allowances: pension, disability and survivors benefits. It is envisaged to maintain the current health and maternity benefits. The proposed law would ensure lifetime health insurance as well as pension allowance - at a floor of 80 percent of the minimum wage - and cap the wages subject to contributions at seven times the minimum wage. It will also regulate contributions of employers to the social security system and will facilitate mobility as it would make it easier for employees to transfer liabilities when workers change jobs and secure full retirement rights of employers throughout their careers. The new law provides pension for all retirees between the ages of 64 and 68 and regulates early retirement for employees aged 60 whose membership period is at least twenty year. ${ }^{1}$

1 The draft law also describes the sources of funding of the new system and provides regulations for the transitory period. Some recommendations from an actuarial study conducted by the ILO on the draft proposal (ILO, 2013) included adding a notional interest rate linked to inflation to individual accounts, gradually increasing retirement age in line with increasing life expectancy, setting the minimum pension at 75 percent of the minimum wage, correctly calculating the starting balance of existing EOSI individual accounts that will be shifted to the new system, and investing the funds of the system in tradable long-term treasury bills.

\section{Unified System}

Addressing sustainability as well as equity aspects would require a transition to a unified pension system. Key reform initiatives have included:

- The 2004 proposal. The authorities, with technical assistance from the World Bank, embarked on a pension reform program in 2004 that aimed at integrating the public and private 
pension schemes into one modern fully-funded defined contribution (FF-DC) scheme. The integrated system was supposed to include: a minimum pension guarantee (MPG) to those who had contributed sufficiently; a flat indemnity to individuals who had not made enough contributions; and preservation of acquired rights under the existing system. Private sector workers, new civil servants and military personnel would join the new FF-DC system, while contributors to the current civil and military schemes could choose to move to the new system on a voluntary basis. Coverage under the new system would be extended to the informal sector, the self-employed and casual workers with limited saving capacity by allowing optional enrollment and providing better enrollment incentives. To date, the proposal has not been implemented.

- The 2011 proposal. A more recent proposal entailed the adoption of a "Notional Defined Contribution" plan following advice from the World Bank and International Labor Organization (World Bank and ILO, 2011). ${ }^{8}$ In this proposal, working individuals would pay contributions from their salaries to fund benefits received by the retired population. The system would grant a 2 percent annual rate of return and an annual inflation-proofing measure. The pension would guarantee at least 40 percent of the last salary for someone with 30 years of contributions, with a reduced pension available after 15 years of contributions. While similar to the 2004 proposal with respect to annuitizing the lump-sum payment and offering a minimum pension guarantee, the 2011 scheme would also include: extension of medical insurance after retirement, the provision of a contributory minimum wage, and a non-contributory pension scheme to all citizens to be funded by taxes.

\section{CONCLUSIONS}

Lebanon will likely face significant demographic challenges in the future. The country faces the least favorable demographics among MENA countries, with the highest life expectancy and the lowest fertility rate, translating into the highest current and projected dependency ratio in the MENA region.

Reform of Lebanon's pension system is indispensable. Sustainability considerations suggest the need for early and gradual reform before pension dynamics drastically deteriorate. As demonstrated by the projections, the longer adjustment is delayed, the costlier it becomes - all indicators worsen markedly beyond 2020, with exponential increases beyond 2030. Despite these unfavorable trends, no reform has been implemented so far, notwithstanding the concrete reform proposals prepared by the authorities in collaboration with international organizations since the early 2000s. Guided by these proposals, it would be useful to consider at least partial reforms in selected parameters of the schemes to help contain fiscal sustainability risks. For the public and private sectors these could include an increase in retirement age - particularly relevant given the country's relatively high life expectancy - as well as an increase in social contributions. Reforms in the public scheme could also include indexing benefits to inflation rather than keeping them linked to wages; and eliminating additional lump-sum payments.

In addition to sustainability issues, equity shortcomings are also a concern. The low number of beneficiaries, in the context of Lebanon's already weak social safety net and aging population, call for action - drawing again from the extensive work done by the authorities in collaboration with international organizations. The most recent draft proposal to reform the private sector scheme is an important effort to reduce inequity by providing lifetime health insurance and pension allowance.

\footnotetext{
Such plan differs from the funded system in two important ways: (i) the interest rate is set by the government and not set by the market; and (ii) the accumulation is only notional so the system is not fully funded and may be equivalent to a pay-as-you-go scheme.
} 
Tackling both sustainability and equity would however require a unified pension system, with related transition costs, not included in this paper. Important aspects of a unified system would be a minimum pension guarantee, flat indemnity, wider coverage, extension of medical insurance after retirement, the provision of a contributory minimum wage, and a tax-funded noncontributory pension scheme for all citizens. These are difficult reforms that require political consensus. While the latter is currently lacking, continued inaction will only turn a difficult problem into an intractable issue.

\section{References}

El Daher, Samir, 2012, "Lebanon Unsustainable Pension Scheme" (mimeo).

International Labor Organization, 2013, "Lebanon's long awaited pension reform within reach" http://www.ilo.org/ global/about-the- ilo/newsroom/features/WCMS_207664/lang--en/index.htm.

—_ and World Bank, 2011, "Joint World Bank and ILO Letter on Government Reform Proposal on Pension."

International Monetary Fund, 2014, Equitable and Sustainable Pensions. Challenges and Experience, ed. by Benedict Clements, Frank Eich, and Sanjeev Gupta (Washington: International Monetary Fund).

_ 2015, "Lebanon: 2015 Article IV Consultation - Press Release; Staff Report; and Statement by the Executive Director for Lebanon" IMF Country Report No. 15/190 (Washington) http://www.imf.org/external/pubs/cat/ longres.aspx?sk=43092.0.

Government of Lebanon, By-law of the Retirement, Disability and Death System, 2013.

Jarmuzek, Mariusz and Najla Nakhle International Monetary Fund, 2016, Sustainability and Equity Challenges: Some Arithmetic on Lebanon's Pension System (Washington: International Monetary Fund, WP/16/46)

Lebanese Economic Association, 2014. "The Right for Pension and Social Security: the current legislative framework and proposed recommendations" http://leb- econ.org/kre/wp-content/uploads/2013/11/\%D8\%A7\%D9\%84\%D8 \%AD\%D9\%82-\%D9\%81\%D9\%8A-\%D8\%A7\%D9\%84\%D8\%AA\%D9\%82\%D8\%A7\%D8\%B9\%D8\%AF\%D9\%88\%D8\%A7\%D9\%84\%D8\%AD\%D9\%85\%D8\%A7\%D9\%8A\%D8\%A9-\%D8\%A7\%D9\%84\%D8\%A 7\%D8\%AC\%D8\%AA\%D9\%85\%D8\%A7\%D8\%B9\%D 9\%8A\%D8\%A9.pdf.

Loewe, Markus, 2013,"Pension Schemes and Pension Reforms in the Middle East and North Africa," German Development Institute.

Pallares-Miralles, Montserrat, Carolina Romero, and Edward Whitehouse, 2012, "International Patterns of Pension Provision II. A Worldwide Overview of Facts and Figures" (Washington: World Bank).

Rached, Mounir, 2012, "Social Security and Pensions in Lebanon: A Non-Contributory Proposal," Lebanese Economic Association and IDRC.

Soto, Mauricio, Vimal Thakoor, and Martin Petri, 2015, "Pension System in Mauritius: Fair and Fast - Balancing Social Protection and Fiscal Sustainability," IMF Working Paper 15/126 (Washington: International Monetary Fund).

Yount, Kathryn and Abla Sibai, 2008, "Demography of Aging in Arab Countries," International Handbooks of Population Volume 1, 2009, pp. 277-315.

World Bank, 2005, "Toward an Integrated Pension System: Reforming the End-of-Service Indemnity Program and The Civil Service and Military Pension Funds."

_ 2005 , "Lebanon Quarterly Update, First Quarter 2005” (Beirut: World Bank). 


\section{APPENDIX}

Table A1.

Key Parameters of the Public Sector and Military Pension Schemes

\begin{tabular}{|c|c|c|}
\hline & Civil Servants & Military \\
\hline Retirement Age & $\begin{array}{l}\text { No requirement. } \\
\text { Maximum retirement age } 64 \text {. } \\
\text { Female teachers can generally retire after } 20 \text { years of service; } \\
\text { male teachers after } 25 \text { years. }\end{array}$ & $\begin{array}{l}\text { No requirement. Maximum } \\
\text { retirement age } 58-64 \\
\text { depending on rank. }\end{array}$ \\
\hline \multirow[t]{4}{*}{ Benefit Rate } & $\begin{array}{l}\text { Less than } 20 \text { years of service: end-of-service compensation. } \\
\text { At least } 20 \text { years of service: choice between lifetime pension } \\
\text { or end-of-service lump-sum. } \\
\text { More than } 40 \text { years of service: a combination of a lifetime } \\
\text { pension and end-of-service compensation. }\end{array}$ & $\begin{array}{l}\text { Credited years of service } \\
\text { up to three years per } \\
\text { effective year depending } \\
\text { on the security alert level. }\end{array}$ \\
\hline & $\begin{array}{l}\text { End-of-service compensation: } 85 \text { percent of last monthly } \\
\text { basic salary }{ }^{1} \text { times one month for each year of service for the } \\
\text { first } 10 \text { years; two months for each year of service in excess } \\
\text { of } 10 \text { years but less than } 20 \text { years; and three months for each } \\
\text { year of service in excess of } 20 \text { years. }\end{array}$ & Same as civil servants. \\
\hline & $\begin{array}{l}\text { Lifetime pension: accrual factor of } 21 / 8 \text { th percent of the last } \\
\text { monthly basic salary for each year of service and fractions } \\
\text { thereof up to a maximum of } 85 \text { percent. }\end{array}$ & Same as civil servants. \\
\hline & $\begin{array}{l}\text { Combined lifetime pension and end-of-service compensation } \\
\text { (for more than } 40 \text { years of service): } \\
85 \text { percent of the last monthly basic salary as a life-pension } \\
\text { and an end-of-service compensation at } \\
85 \text { percent of last monthly basic salary times three months } \\
\text { for each year of service that exceeds } \\
40 \text { years. }\end{array}$ & Same as civil servants \\
\hline
\end{tabular}

Contribution Rate 6 percent of basic salary; ${ }^{2}$ retirees do not contribute.

Same as civil servants.

Pension Indexation Ad hoc basis. The last pension increase was granted in 2012 Same as civil servants. based on the 2008 salary categories.

Other Benefits Survivor benefits for employees who die during service; $\quad$ Same as civil servants. disability pension for employees who qualify.

\footnotetext{
1 The last monthly basic salary is the pay scale, except for teachers, where special allowances are included in calculating the pension amount.

2 The 2003 budget included a request to increase the contribution rate to 8 percent starting in FY2003 but it was not approved by parliament

Source: World Bank (2005).
} 
Table A2.

Key Parameters of the End of Service Indemnity (EOSI)

Retirement age Maximum age 64. Beyond that no accruals to the EOSI despite continued coverage under other benefits.

Benefit Rate Share of entitlements if the employee completed at least 20 years of service, ${ }^{1}$ reached age 60 or older; in case of marriage (during the first year and for females only), death (prior to retirement with at least six months of service), and disability (subject to a minimum of 20 times the monthly earnings). The monthly earnings used to determine the EOSI is equal to one-twelfth of the taxable earnings in the year preceding the date of entitlement. If the individual resumes work subsequent to the pre-age 60 liquidation, he or she can only liquidate subsequent accrual upon reaching age 60 , death, or disability.

Contribution Rate ${ }^{2}$ None from the employee. Employers contribute on behalf of each employee at the rate of 8.5 percent of the individual's taxable income (of which 0.5 percentage points to the NSSF administration). However, effective employer contribution rates are higher since the last employer pays the shortfall between the employee's entitlement with the last employer and the accumulated contributions with interest corresponding to the same employment period.

Coverage Private sector employees, contractual government employees, taxi drivers, newspaper and magazine vendors, local councilors and voluntary self-employed subscribers.

Investment Contributions are collected in individual accounts and accrue an interest rate determined by NSSF investments - usually the rate on government bonds as most of NSSF investments are in treasury paper.

Other Benefits Upon claim of indemnity, employers add one month of salary for every year the employee has spent with them (up to 20 years), and

1.5 months for every year after that. Accumulated contributions are managed by the NSSF.

1 Employees with less than 20 years of contributions are subject to a reduction schedule of entitlements as follows: less than 5 years contribution, 50 percent reduction; between 5 and 10 years contribution, 35 percent reduction; between 10 and 15 years contribution, 25 percent reduction; between 15 and 20 years contribution, 15 percent reduction.

2 The total social security contribution is set at 23.5 percent ( 21.5 percent paid by the employer and 2 percent paid by the employee). The employer pays 6 percentage points to the health insurance, 6 percentage points to the family allowances, and 8.5 percentage points to the EOSI. The employees' share only covers health insurance.

Source: World Bank (2005) 